\title{
Prediction of the Impact Sensitivity of Aluminized Explosive Mixtures Using the Response Surface Methodology
}

\author{
Zoran Bajić ${ }^{1)}$ \\ Radun Jeremić $^{1)}$ \\ Dušan Jevremović ${ }^{2)}$ \\ Jovica Bogdanov ${ }^{1)}$
}

\begin{abstract}
The possibility of the impact sensitivity prediction based on the physicochemical properties and element composition of explosives contributes to a faster research of novel high explosives (HE), reduces the research costs and helps to improve the explosive safety. This paper analyzes the existing methods for the prediction of impact sensitivity and introduces a response surface methodology (RSM). The new method comprises a correlation between impact sensitivity and two primary properties of HE: detonation velocity and heat of detonation. Calculated impact sensitivities are compared to the experimental values taken from the literature in order to validate the approach.
\end{abstract}

Key words: explosive mixture, high explosives, aluminized explosives, explosives sensitivity, impact sensitivity, prediction method.

\section{Introduction}

$\mathrm{T}$ HE research in the field of high explosives (HE) has a growing tendency to achieve better explosive performance that is often accompanied with the energy content increase. The higher energy content almost inevitably leads to an increase of HE sensitivity and a reduction in safety [1]. Because sensitivity is a major characteristic of $\mathrm{HE}$, it is especially desirable to have a valid method of predicting sensitivity based on the available experimental and calculated data. The performance and sensitivity properties of a candidate for a new high explosive as well as for a new HE mixture are very important because its development, manufacture and testing is cost effective, environmentally desirable and because of its time saving capabilities. Since safe handling is one of the most important issues to the scientists and engineers who handle HE, the correct estimation of the explosive safety presents substantial significance [2].

The study of explosives by the theoretical methods has provided an extensive insight for identification of promising and elimination of undesirable candidates for an additional consideration. Numerous studies have been done to relate impact sensitivity to various properties of pure $\mathrm{HE}$ such as oxygen balance [3-5], quantum chemical calculation [6-9], physicochemical properties and elemental composition of $\mathrm{HE}$ [2,10-13], quantitative structureproperty relationship (QSPR) models using computational data mining methods [14-19] etc. Detonation velocity and the heat of detonation are used in this paper to predict impact sensitivity of the selected mixtures of aluminized HE. The purpose of this paper is to predict a simple correlation between impact sensitivity of the aluminized HE mixtures and chosen detonation parameters using the response surface methodology [20]. The coefficients of the response function and their statistical significance were evaluated by the least squares method using the DesignExpert v.9.0 software, Stat-Ease, Inc.

\section{Impact sensitivity prediction models}

One of the important factors in assessing of the HE is its susceptibility to detonation caused by accidental or intentional impact stimuli. Drop weight or drop hammer test is one of the most frequent tests used for evaluation of the impact sensitivity [21]. The drop weight impact test is convenient method by which few milligrams of an explosive material are placed between the steel anvil and the striker. Different criteria are used in order to judge whether the reaction has occurred. Unfortunately, it is highly subjective that the judgment of the test apparatus operator is relied upon to detect the smell from or sound of an event if a flash does not occur. Since the initiation by an impact is extremely complicated, reported data serve only as an approximation indication of sensitivity. The results of a drop weight impact measurement are not often reproducible and give widely varying $h_{50}$ values in some cases $[12,21]$.

The initiation of explosions on the test machine has a probabilistic nature, i.e., at a fixed weight drop height $h$ in a series of parallel experiments, explosions occur with a certain probability (frequency) $f=N_{+} / N_{0} \cdot 100 \%$, where $N_{+}$is a number of explosion reactions that was detected and $N_{0}$ is a total number of experiments in the series. As $h$ increases in the range $h_{0}<h<h_{100}$, the probability of explosions changes in the interval $f=0-100 \%$. The dependence $f(h)$ in a graphical representation is called the explosion frequency curve.

\footnotetext{
1) University of Defense, Military Academy, Generala Pavla Jurišića Šturma 33, 11000 Belgrade, SERBIA

2) Serbian Armed Forces, Nemanjina 15, 11000 Belgrade, SERBIA

Correspondence to: zoran.bajic@,va.mod.gov.rs
} 
The most reliable point of this dependence is the quantity $h_{50}$ for which $f=50 \%[12,22-24]$. Hence, $h_{50}$ denotes the height in centimetres, at which the probability of explosion is $50 \%$.

Theoretical studies of energetic materials have provided a considerable insight into understanding of factors affecting their behaviour. Out of numerous studies of correlations of impact sensitivities with various molecular features, structural and electronic, Kamlet and Adolph [3,4] introduced a very simple conventional scheme that can be applied to a large number of HE. In their work, the impact sensitivity is linearly related to a measure of oxygen balance by the following equation:

$$
\log h_{50}=a_{1}+a_{2} O B_{100}
$$

The constants $a_{1}$ and $a_{2}$ have different values for various classes of $\mathrm{C}_{a} \mathrm{H}_{b} \mathrm{~N}_{c} \mathrm{O}_{d}$ explosives. $O B_{100}$ is oxygen balance of $\mathrm{HE}$ and is calculated as follows:

$$
O B_{100}=2 d-b-2 c-2 n\left(C O_{2}\right) / M W .
$$

where $n\left(\mathrm{CO}_{2}\right)$ is the number of $\mathrm{CO}_{2}$ moieties, e.g. in esters or carboxylic acids, that are contained in the molecule and $M W$ is the molecular weight of explosive. Letters $a, b, c$ and $d$ stand for HE equivalent formula coefficients.

Škare and Sućeska [5] presented a similar concept applicable for all classes of HE given in the next equation.

$$
\log h_{50}=1.73-0.320 B_{100}
$$

The coefficient of determination (COD) for the selected HE using Equation 3 was 0.96 [5].

Rice and Hare [6] introduced five models based on the quantum mechanical calculations of the individual molecules using parameters related to the features of the surface electrostatic potentials (Equations 4-8).

$$
\begin{gathered}
h_{50}=p_{1}+q_{1} \exp \left(r_{1} \bar{V}_{M}\right)-s_{1} \bar{V}_{M} \\
h_{50}=p_{2}+q_{2} \exp \left(r_{2}\left|\bar{V}^{+}\right|-\left|\bar{V}^{-}\right|\right) \\
h_{50}=p_{3}+q_{3} \exp \left(r_{3} v\right) \\
h_{50}=p_{4}+q_{4} \exp \left(r_{4}\left(Q_{\operatorname{det}}-s_{4}\right)\right) \\
h_{50}=p_{5} \exp \left(q_{5} v-r_{5}\left(Q_{e t}-s_{5}\right)\right)
\end{gathered}
$$

where $h_{50}$ is in $\mathrm{cm}, V_{M}$ is the approximate electrostatic potential at the midpoint of each bond in $\mathrm{kcal} \mathrm{mol}^{-1}, V^{+}$and $V$ are the averages of the positive and negative values of the electrostatic potential on the molecule isosurface in kcal $\mathrm{mol}^{-1}, v$ is the balance parameter of the generalized interaction property function, and $Q_{\text {det }}$ is the heat of detonation in $\mathrm{kcal} \mathrm{g}^{-1}$. Parameters in the Equations 4-8 are as follows: $p_{1}=63.6, q_{1}=18900, r_{1}=-0.089, s_{1}=0.0367$, $p_{2}=9.2, q_{2}=803, r_{2}=-0.366, p_{3}=29.3, q_{3}=0.00138, r_{3}=$ $48.84, p_{4}=27.8, q_{4}=0.1135, r_{4}=-11.079, s_{4}=1.661, p_{5}=$ $1.341, q_{5}=8.1389, r_{5}=6.7922$ and $s_{5}=1.4737$.

Keshavarz $[2,10,11]$ gave several approaches in the impact sensitivity estimation primarily based on the elemental structure of HE. Eqs 9-11 [2] can be used for $\mathrm{C}_{a} \mathrm{H}_{b} \mathrm{~N}_{c} \mathrm{O}_{d}$ polynitroaliphatic, polynitroaromatic (including benzofuroxane) and nitramine explosives, respectively.

$$
\begin{gathered}
\log h_{50}=81.40 a+16.11 b-19.08 c+1.089 d / M W \\
\log h_{50}=11.76 a+61.72 b+26.89 c+11.48 d / M W \\
\log h_{50}=47.33 a+23.50 b+2.357 c-1.105 d / M W
\end{gathered}
$$

Coalescing oxygen balance and some structural parameters of HE Keshavarz [10] suggested next general equation.

$$
\log h_{50}=y_{1}+y_{2}\left(\frac{100\left(a+\frac{b}{2}-d\right)}{M W}\right)+y_{3}\left(\frac{100 c}{M W}\right)+y_{4} n
$$

where $y_{1}-y_{4}$ are adjustable coefficients which can be obtained from the fitting functions of impact sensitivities experimental data and $n$ is a number of $\mathrm{R}-\mathrm{C}\left(\mathrm{NO}_{2}\right)_{2}-\mathrm{CH}_{2}-$ moieties attached to the oxygen of carboxylate functional groups where $\mathrm{R}$ is the alkyl group. Optimized parameters, calculated using multiple linear regression method, have the following values: $y_{1}=2.47, y_{2}=0.371, y_{3}=-0.485$ and $y_{4}=0.185$.

Denisaev et al. [12] submitted an impact sensitivity estimation for the liquid explosives based on a maximum volumetric heat of the explosion presented by the general eq.13. Volumetric heat of explosion is actually a mass heat of explosion multiplied with the HE density.

$$
\sqrt{h_{50}}=a-b \rho Q_{\max }
$$

where $Q_{\max }$ is in $\mathrm{kcal} \mathrm{g}^{-1}$. Parameters $a, b$ and COD for different classes of liquid $\mathrm{HE}$ are as follows.

For nitramines, $a=35.1, b=11.0$ and COD $=0.894$.

For nitroaromatics, $a=40.4, b=14.6$ and COD $=0.990$.

For nitrates, $a=33.2, b=11.6$ and COD $=0.966$.

For nitroaliphatics, $a=30.0, b=10.6$ and COD $=0.899$.

For azides, $a=23.2, b=8.0$ and $\mathrm{COD}=0.900$.

Smirnov et al. [13] found a correlation between the impact sensitivity of $\mathrm{HE}$ and heat of detonation, density, melting temperature and atom mass in $1 \mathrm{~kg}$ of $\mathrm{HE}$ reaching a high COD value of 0.994 .

$$
h_{50}=0.01(\rho B)^{2} Q_{\max }^{-0.9022}\left(500-T_{m}\right)^{0.5565}
$$

where $h_{50}$ is in $\mathrm{J}, \rho$ is in $\mathrm{g} \mathrm{cm}^{-3}, B$ is in $\mathrm{g}$ atom $\mathrm{kg}^{-1}, Q_{\text {max }}$ is in $\mathrm{kcal} \mathrm{kg}^{-1}$ and $T_{m}$ is in ${ }^{\circ} \mathrm{C}$.

\section{Response surface methodology}

Generally, the impact sensitivity prediction methods, given in the literature, deal with pure HE. This approach is quite satisfactory when it comes to the investigation of new HE. On the other hand, for the analysis of explosive mixtures already in use or for new mixtures, there are no suitable methods. The main reason for that is the variety of components used in mixtures and their different features. RSM that can be applied to aluminized HE mixtures correlates the impact sensitivity to a velocity of detonation and heat of detonation. HE mixtures composition is given in Table 1.

A two-variable design of the impact sensitivity optimization using the selected independent parameters was performed. The actual variable values are summarized in Table 2. The ranges of the independent values are taken from the available data for the HE mixtures. 
Table 1. Composition of investigated aluminized HE mixtures

\begin{tabular}{|c|c|c|c|c|c|c|}
\hline HE & HMX & RDX & TNT & Al & Binder & Ref. \\
\hline \hline HBX-1 & - & 40 & 40 & 20 & - & {$[25]$} \\
\hline HBX-3 & - & 30 & 30 & 35 & - & {$[25]$} \\
\hline H-6 & - & 45 & 30 & 20 & 5 & {$[25]$} \\
\hline HTA-3 & 50 & - & 30 & 20 & - & {$[25]$} \\
\hline Tritonal & - & - & 80 & 20 & - & {$[25]$} \\
\hline C. B + Al & - & 54 & 36 & 10 & - & {$[26]$} \\
\hline TGAF-5M & - & 59 & 19 & 17 & 5 & {$[27]$} \\
\hline TOKAF & 60 & - & 18 & 17 & 5 & {$[27]$} \\
\hline PVV-7 & - & 71.5 & - & 17 & 11.5 & {$[27]$} \\
\hline PE-6 & - & 72.2 & - & 15 & 12.8 & {$[27]$} \\
\hline MS-1 & - & 57 & 19 & 17 & 7 & {$[27]$} \\
\hline A-IX-2 & - & 73 & - & 23 & 4 & {$[27]$} \\
\hline
\end{tabular}

Table 2. Experimental values of the explosive parameters for the aluminized HE mixtures

\begin{tabular}{||c|c|c|c|c||}
\hline HE mixture & $h_{50}$ & $\begin{array}{c}Q \\
\mathrm{MJ} \mathrm{kg}^{-1}\end{array}$ & $\begin{array}{c}D \\
\mathrm{~km} \mathrm{~s}^{-1}\end{array}$ & Ref. \\
\hline \hline HBX-1 & 70 & 7.70 & 7.22 & {$[25]$} \\
\hline HBX-3 & 75 & 8.83 & 6.92 & {$[25]$} \\
\hline H-6 & 75 & 8.70 & 7.19 & {$[25]$} \\
\hline HTA-3 & 43 & 4.98 & 7.87 & {$[25]$} \\
\hline Tritonal & 74 & 7.41 & 6.52 & {$[25]$} \\
\hline Comp. B + Al & 60 & 5.93 & 7.60 & {$[25]$} \\
\hline TGAF-5M & 60 & 6.28 & 7.70 & {$[26]$} \\
\hline TOKAF & 60 & 6.53 & 7.86 & {$[27]$} \\
\hline PVV-7 & 70 & 6.28 & 6.50 & {$[27]$} \\
\hline PE-6 & 65 & 6.49 & 6.80 & {$[27]$} \\
\hline MS-1 & 60 & 6.10 & 7.60 & {$[27]$} \\
\hline A-IX-2 & 60 & 6.48 & 8.40 & {$[27]$} \\
\hline
\end{tabular}

The experimental design consisted of 12 runs. Each experimental design run was performed in triplicates and the data produced were averaged with the standard deviations. The Design-Expert v.9.0 software was used for the regression and graphical analysis of the experimental data. ANOVA was performed in order to evaluate the statistical significance of the model.

\section{Results and discussion}

The $h_{50}$ value of impact sensitivity is considered as the output variable. Adequacy of the two-factor interaction regression model was proved by the ANOVA test, significance of the model coefficients in eq. 15 was tested using the Student test (Fig.1).

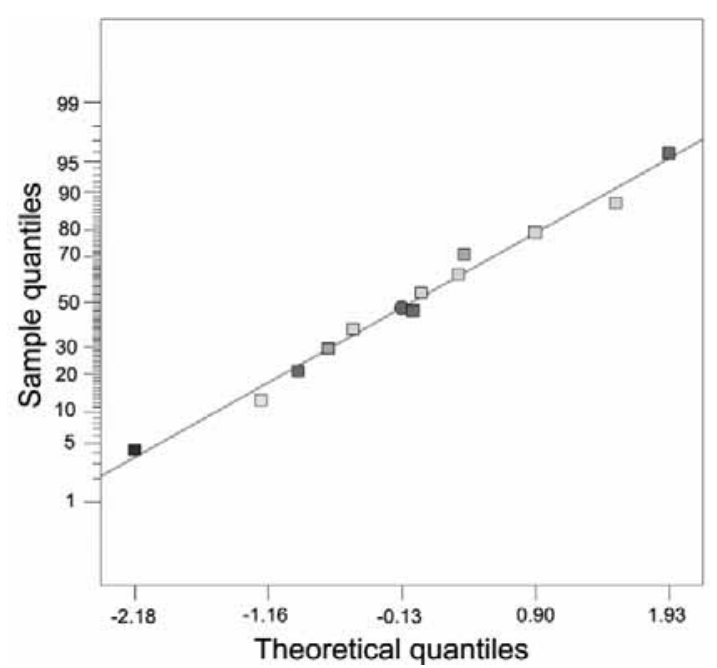

Figure 1. Normal probability plot for studentized residuals of the experimental data
The ANOVA results indicate that two-factor interaction model is significant $(F$ value $=47.1)$ with a standard deviation of 2.50 and with $p$-value $<0.0001$. The adjusted $R^{2}$ value of 0.9263 was in a reasonable agreement with the predicted $R^{2}$ value of 0.7797 , with a signal to noise ratio of 21.4. All the variables showed both individual and interacting significant effect on the output. The quantitative effects of the velocity of detonation $(D)$ and heat of detonation $(Q)$ as independent variables and their interactions on the impact sensitivity $\left(h_{50}\right)$ as the output variable are given in eq. 15.

$$
h_{50}=388.26-49.75 D-42.62 Q+6.67 D Q
$$

The comparison between the experimental and calculated $h_{50}$ values (using eq.15) shows that the predicted model is in a good agreement with the experimental data with standard error of 2.21, average relative error of 3.29 and chi square 1.41E-04. Fig.2 shows a linear correlation plots between the actual and predicted values of the impact sensitivity. Used model gives correlation coefficient 0.9463 suggesting its good agreement with the experimental data.

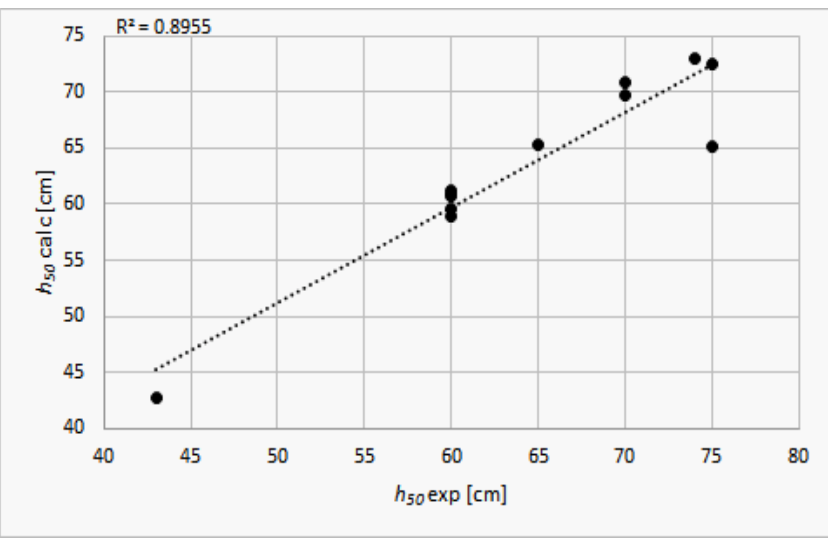

Figure 2. Linear correlation plot between the experimental and calculated impact sensitivity

The contour and 3D plots of the relationship between the impact sensitivity and velocity of detonation and heat of detonation is shown in Figures 3 and 4.

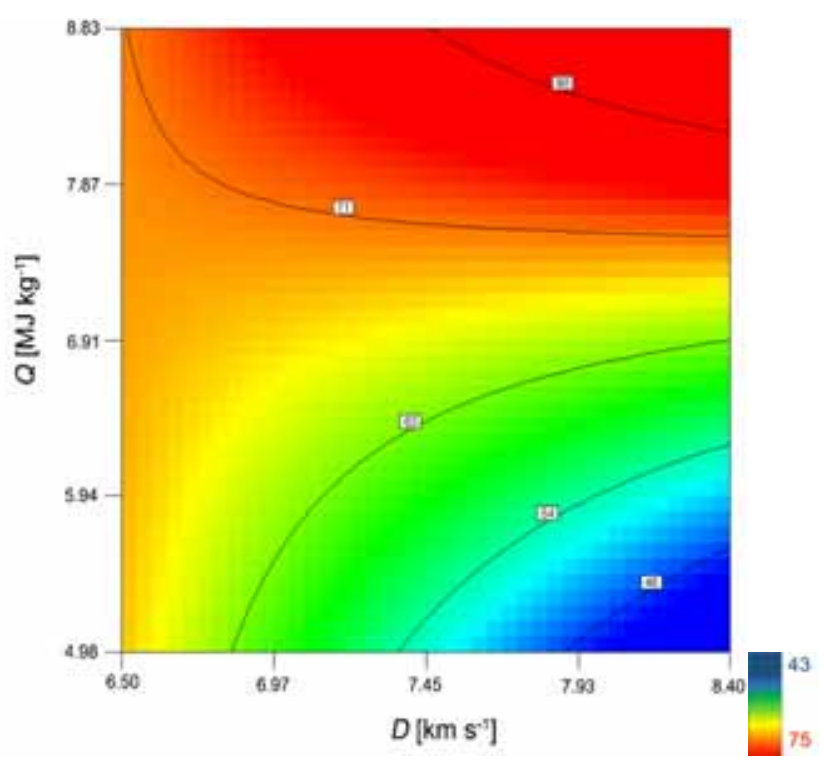

Figure 3. 2D plot of detonation velocity and heat of detonation influence on impact sensitivity 


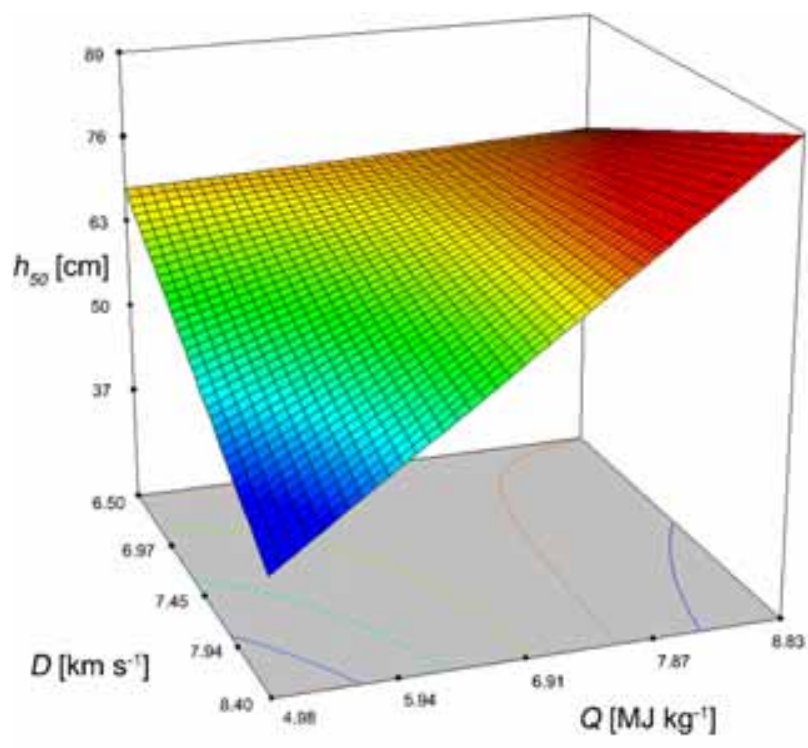

Figure 4. 3D plot of detonation velocity and heat of detonation influence on impact sensitivity

Optimization of the independent variables in order to achieve a maxed impact sensitivity is conducted through the multiple response method of a desirability [28]. The desirability will be 1 for the optimized impact sensitivity if the detonation velocity is greater than $6.9 \mathrm{~km} \mathrm{~s}^{-1}$ and the heat of detonation is greater than $7.9 \mathrm{MJ} \mathrm{kg}^{-1}$.

\section{Conclusion}

Presented method for impact sensitivity prediction of the aluminized HE shows a good agreement with the experimental data taking into account that their different values are often identified in various reported experiments. Coefficient of determination for the observed HE is 0.9463. This simple equation uses parameters essential for aluminized HE but does not consider aluminium particle size, charge density, other metallic compounds and presence of oxidizers i.e. nitrates and perchlorates.

\section{Literature}

[1] MADER, C.L. Numerical modeling of explosives and propellants, $2^{\text {nd }}$ edition, CRC Press, 1998.

[2] KESHAVARZ,M.H. POURETEDAL,H.R.: Simple empirical method for prediction of impact sensitivity of selected class of explosives, Journal of Hazardous Materials A124, 2005, pp.27-33.

[3] KAMLET,M.J.: The relationship of impact sensitivity with structure of organic high explosives. I. Polynitroaliphatic explosives, in: Proc. $6^{\text {th }}$ Symp. (Int.) on Detonation (Washington, August 24-27, 1976), San Diego, 1976, pp.276-288.

[4] KAMLET,M.J. ADOLPH,H.G.: The relationship of impact sensitivity with structure of organic high explosives, II. Polynitroaromatic explosives, Propellants Explos., 1979, 4, pp.3034.

[5] ŠKARE,D. SUĆESKA,M. Molecular mass/density and oxygen content/sensitivity relationships, Croat. Chem. Acta, 1998, 71 (3), pp.765-776.

[6] MULLAY,J.A.: Relationship between impact sensitivity and molecular electronegativity, Propellants Explos., 1987, 12, pp.6063.

[7] MULLAY,J.: Relationships between impact sensitivity and molecular electronic structure, Propellants Explos., 1987, 12, pp.121-124.
[8] RICE,B.M., HARE,J.J.: A quantum mechanical investigation of the relation between impact sensitivity and the charge distribution in energetic molecules, J. Phys. Chem. A 106, 2002, pp.1770-1783.

[9] GOLUBEV,V.K.: Influence of structural and energetic factors on impact sensitivity of aromatic nitro compounds, Proceedings of $14^{\text {th }}$ Symposium on New Trends in Research of Energetic Materials, Pardubice, Czech Republic, 2011.

[10] KESHAVARZ,M.H.: Prediction of impact sensitivity of nitroaliphatic, nitroaliphatic containing other functional groups and nitrate explosives, Journal of Hazardous Materials, 2007, 148, pp.648-652.

[11] KESHAVARZ,M.H.: A new general correlation for predicting impact sensitivity of energetic compounds, Propellants Explos., 2013, 38, pp.754-760

[12] DENISAEV,A.A., KORSUNSKII,B.L., PEPEKIN,V.I. ,MATYUSHIN,Yu.N.: Impact sensitivity of liquid explosives, Combustion, Explosion, and Shock Waves, 2010, 46 (1), pp.74-80.

[13] SMIRNOV,A., VORONKO, KORSUNSKY,O.B., PIVINA,T.: Impact sensitivity investigations of individual explosives, Proceedings of $16^{\text {th }}$ Symposium on New Trends in Research of Energetic Materials, Pardubice, Czech Republic, 2013.

[14] KESHAVARZ,M.H., JAAFARI,M.: Investigation of the various structure parameters for predicting impact sensitivity of energetic molecules via artificial neural network, Propellants Explos., 2006, 31, pp.216-225.

[15] NEFATI,H., CENSE,J.M., LEGENDRE,J.J.: Prediction of the impact sensitivity by neural networks, J. Chem. Inf. Comput. Sci., 1996, 36, pp.804-810.

[16] CHO,S.G., NO,K.T., GOH,E.M., KIM,J.K., SHIN,J.H., JOO,Y.D., SEONG,S.: Optimization of neural networks architecture for impact sensitivity of energetic molecules, Bull. Korean Chem. Soc., 2005, 26, pp.399-408.

[17] WANG,R.,JIANG,J.C., PAN,Y., CAO,H.Y., CUI,Y.: Prediction of impact sensitivity of nitro energetic compounds by neural network based on electrotopological state indices, J. Hazard. Mater., 2009, 166, pp.155-186.

[18] PRANA,V., FAYET,G., ROTUREAU,P., ADAMO,C.: Prediction of impact sensitivity of nitro energetic compounds using OSPR approaches, in: Proc. $14^{\text {th }}$ Sem. (Int.) on New Trends in Research of Energetic Materials (Pardubice, April 13-15, 2011), Czech Republic, 2011 pp.305-315.

[19] PRANA,V., FAYET,G., ROTUREAU,P., ADAMO,C.: Development of validated QSPR models for impact sensitivity of nitroaliphatic compounds, J Haz Mat, 2012, 235-236, pp.169-177.

[20] IHAKA,R., GENTLEMAN,R.R.: A language for data analysis and graphics, J Comp Graph Stat, 1996, 5, pp.299-314.

[21] ZUKAS,J.A., WALTERS,W.P.: (Eds), Explosive effects and applications, Springer-Verlag New York, 1998.

[22] State Standard GOST 4545-80: Explosive substances. Methods of determining impact sensitivity [in Russian], Izd. Standartov, Moscow, 1981.

[23] [NATO Standardization agreement (STANAG) on explosives, impact sensitivity tests, No. 4489, Ed. 1, Brussels, 1999.

[24] ŠELEŠOVSKÝ,J., PACHMAN,J.: Probit analysis - a promising tool for evaluation of explosive's sensitivity, Central European Journal of Energetic Materials, 2010, Vol.7, No.3, pp.269-278.

[25] Department of the Army Technical Manual, Military explosives, Headquarters, Department of the Army, 1984.

[26] VADHE,P.P., PAWAR,R.B., SINHA,R.K., ASTHANA,S.N. ,SUBHANANDA RAO,A.: Cast aluminized explosives (Review), Combustion, Explosion, and Shock Waves, 2008, Vol.44, No.4, pp.461-477.

[27] ORLENKO,L.P.: (Ed), Fizika vzryva [in Russian], Ed. 3, Fizmatlit, Moscow, 2004.

[28] MYERS,R.H. MONTGOMERY,C.M.: Response Surfaces Methodology: Process and Product Optimization Using Designed Experiments, Wiley, New York, 1995. 


\title{
Predviđanje osetljivosti na udar aluminiziranih eksplozivnih smeša korišćenjem metode response surface methodology
}

\begin{abstract}
Mogućnost predviđanja osetljivosti na udar na osnovu fizičko-hemijskih osobina i elementarnog sastava eksploziva doprinosi brzini procesa istraživanja eksplozivnih materija, smanjuje troškove i poboljšava pirotehničku bezbednost. $U$ ovom radu se analiziraju postojeće metode za predviđanje osetljivosti na udar i uvodi se metodologija odzivnih površina (response surface methodology - RSM). Nova metoda omogućava kreiranje korelacije između osetljivosti na udar i dve osnovne osobine eksplozivnih materija: brzine detonacije i toplote detonacije. Izračunate vrednosti osetljivosti na udar su upoređene sa eksperimentalnim koje su preuzete iz literature sa ciljem ocene ovog pristupa

Ključne reči: eksplozivna smeša, brizantni eksplozivi, aluminizirani eksplozivi, osetljivost eksploziva, osetljivost na udar, metoda procene.
\end{abstract}

\section{Prédiction de la sensitivité l'impact des mélanges explosifs aluminisées par la méthode "response surface methodology"}

\begin{abstract}
La possibilité de prévoir la sensitivité à l'impact à la base des propriétés physiques et chimiques de la composition élémentaire des explosifs contribue à la vitesse du processus des examens des matériaux explosifs, diminue les frais et améliore la sécurité pyrotechnique. Dans ce papier on analyse les méthodes existantes pour la prédiction de la sensitivité à l'impact et on introduit la méthode „,response surface methodology” (RSM). Cette nouvelle méthode permet la création de la corrélation entre la sensitivité de l'impact et les deux propriétés basques des matériaux explosifs: vitesse de détonation et température de détonation. Les valeurs calculées pour la sensitivité de l'impact ont été comparées avec celles expérimentales qui étaient prises dans la littérature dans le but d'évaluer la présente approche.
\end{abstract}

Mors clés: mélange explosif, explosifs brisants, explosifs aluminisés, sensitivité explosive, sensitivité à l'impact, méthode d'évaluation.

\section{Прогнозирование чувствительности к удару (шока) алюминированных взрывоопасных смесей с использованием методологии поверхности отклика (response surface methodology)}

\footnotetext{
Способность предсказывать чувствительность к удару на основе физико-химических свойств и химического состава взрывчатых веществ, таким образом ускоряет процесс исследования взрывчатых материалов, снижает затраты и повышает пиротехническую безопасность. Эта статья анализирует существующие методы прогнозирования чувствительности к удару и вводит методологию поверхности отклика (response surface methodology - RSM). Новый метод позволяет создавать корреляции между чувствительностью к удару и двумя основными характеристиками взрывчатых веществ: скорости детонации и детонации тепла. Расчётные значения чувствительности к удару сравниваются с экспериментальными данными, полученными из литературы с объективной оценкой этого подхода.

Ключевые слова: взрывоопасная смесь, взрывчатые вещества, алюминированные взрывчатые вещества, чувствительность взрывчатых веществ, чувствительность к удару, метод оценки.
} 